\title{
The intake of milk and the retention of its constituents while the newborn rabbit doubles its weight
}

\author{
By J. S. DAVIES, ELSIE M. WIDDOWSON ANd R. A. MCCANCE \\ Medical Research Council Department of Experimental Medicine, \\ University of Cambridge
}

(Received 6 fanuary $1964-$ Accepted 3I Fanuary 1964 )

One of the most interesting, but at the same time unstudied, periods of an animal's nutritional life is what Karl Thomas (I9II) referred to as 'die erste Verdoppelungsperiode des Geburtsgewichtes'. The technical and physiological difficulties of collecting the food, measuring the amount ingested, and gathering the excreta of suckling laboratory animals have so far prevented satisfactory balance experiments being carried out on them, although the accretion rates of any or all of the constituents of the body can easily enough be obtained by direct analysis. Balance experiments are possible, even if tedious, in human babies, but the pitfalls of calculating accretion rates from them have become ever more apparent of recent years (Wallace, Weil \& Taylor, 1958), and there is no way of checking the results by chemical analysis of the bodies.

In a recent contribution to a book on protein metabolism McCance \& Widdowson (1964) set out what information was available about the intake and composition of the food, energy expenditure and the amounts of protein and amino acids required by the rat, pig, calf and human baby while they doubled their birth weights. The interest and importance and at the same time the defects of the comparisons prompted a desire for further evidence and, as Claude Bernard (1865) put it, 'Le choix intelligent d'un animal...est souvent la condition essentielle du succès d'une expérience et de la solution d'un problème physiologique très-important'. The success of the enterprise, in other words, clearly depends upon selecting a suitable animal for the investigation. The rabbit appears to be such an animal.

It was reported by Deutsch (1957) that young rabbits were not suckled so frequently by their mothers as most other animals, and that they were often left for $24 \mathrm{~h}$ without attention. By taking advantage of this fact it has been possible to segregate the young of tame doe rabbits from one morning to the next, to measure the amount of milk consumed by the young by weighing them before and after suckling, and to analyse their bodies at the end of each experiment, and the bodies of litter-mates at the beginning. It was also relatively easy to obtain milk from the mothers or other does for direct analysis, and so to obtain the chemical composition of the food. 
MATERIAL AND METHODS

The rabbits were housed in metal cages $140 \mathrm{~cm}$ long and $50 \mathrm{~cm}$ deep, with a removable partition in the centre. The does were fed on a pelleted diet (Diet SG of Short \& Gammage, 1959), with fresh greens once at week, and water provided continuously.

The young (twenty-seven in all) from twelve Dutch rabbit does have been investigated. Nine were killed on the day of birth, nine at 3 days of age and nine at II days. All those to be killed at I I days, along with others in the same litters, were weighed and separated from the mother by closing the partitition in the cage on the

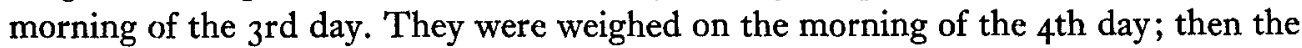
partition was opened. The mother at once moved in and suckled her young, which took 2-3 min. The young were weighed again directly suckling had finished; the mother was separated for another $24 \mathrm{~h}$ and the procedure was repeated each day.

The young rabbits were killed with ether and weighed. The whole of the digestive tract from below the diaphragm was removed. It was divided into three parts, stomach, and small and large intestine (which included the caecum), and each portion was weighed. The length of the small intestine was measured, and the three parts were emptied and weighed again. They were then returned to the carcass and the whole was dried in an oven at $95^{\circ}$ to constant weight. The subsequent treatment of the dried carcass and the methods used for the determination of fat, nitrogen, calcium, magnesium, sodium, potassium, phosphorus and chloride were as described by Cabak, Dickerson \& Widdowson (1963). All twenty-seven young rabbits were used for the anatomical measurements and eight at each age were subjected to chemical analysis.

Milk was collected by manual expression on the $4^{\text {th }}$, $5^{\text {th }}$, 6th, $7^{\text {th }}, 8$ th, 9 th and roth days of lactation after the injection of $0.5 \mathrm{ml}$ Pitocin ( $\equiv 5$ i.u. oxytocin; Parke, Davis and Co.) into a vein in the ear. Duplicate weighed portions of each sample were taken for the determination of total $\mathrm{N}$ by the micro-Kjeldahl method and for lactose by a modification of the Munson-Walker method as described by the Association of Official Agricultural Chemists (1950), anthrone being used for the colorimetric measurement. The remainder of the milk was weighecl in its stoppered tube, washed into a silica crucible and dried at $95^{\circ}$ to constant weight. The fat was extracted by repeated applications of light petroleum (b.p. $40^{\circ}-60^{\circ}$ ), the petroleum removed by evaporation, and the amount of fat determined by weighing. The fat was returned to the silica crucible, the whole dried milk was ashed in a muffle furnace at $460^{\circ}$ and the ash weighed. Subsequent treatment of the ash and methods of mineral analysis were the same as those used for the rabbit carcasses.

\section{RESULTS}

Fig. I shows the gain in weight of a representative young rabbit for the first 3 weeks of its postnatal life. It will be noted that: (I) The gain in weight was less rapid during the first 3 days than afterwards. This was true also of the other young rabbits and the rabbit, therefore, resembles the human rather than most other species of animal in that 
it takes a little time for the milk to 'come in' and for a satisfactory symbiosis between mother and young to establish itself. (2) Owing to the prolonged interval between each suckling the weight increased by a series of spurts separated by almost $24 \mathrm{~h}$ of decline. A young rabbit was able to take a quarter of its own weight of milk in 2-3 min. (3) The birth weight had been doubled by the 6th day, but the weight also doubled itself between the $3^{\text {rd }}$ and the IIth days, and this was the time of the animal's life chosen for the investigation described here.

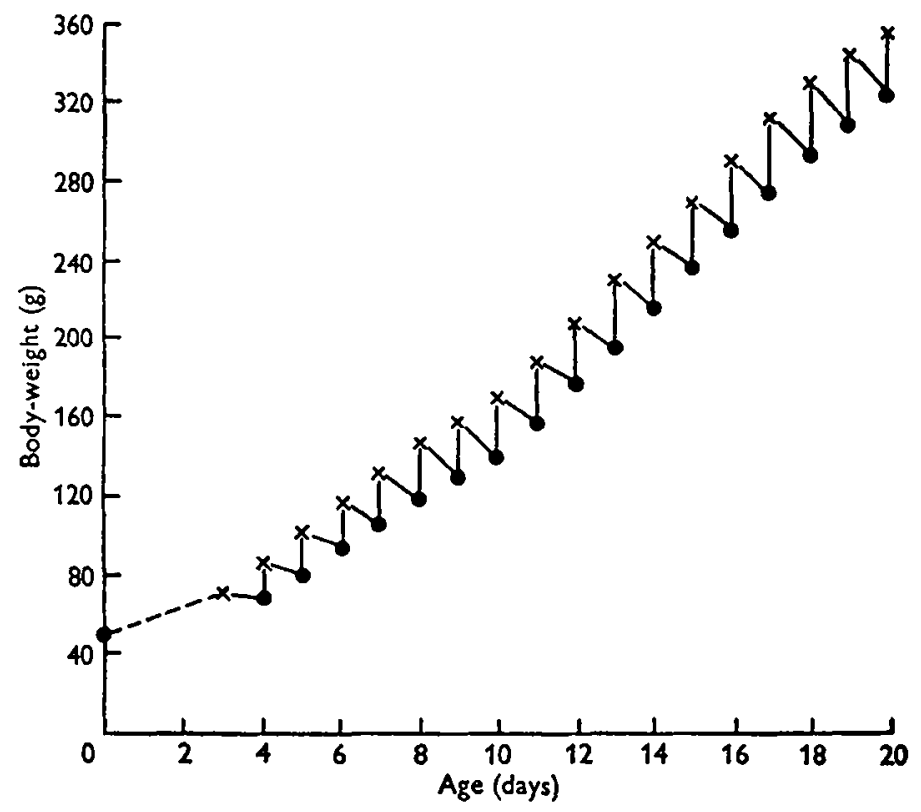

Fig. 1. Gain in weight of a representative young rabbit. $\bullet$, weighed before being suckled; $x$, weighed immediately after being suckled.

Table 1. Composition of rabbit's milk

Mean value with
standard deviation
for seven samples

Water $(\mathrm{g} / \mathrm{1} 00 \mathrm{~g})$

Total N (g/100 g)

Fat $(\mathrm{g} / \mathrm{r} 00 \mathrm{~g})$

Lactose ( $\mathrm{g} / \mathrm{r} 00 \mathrm{~g})$

Calories (kcal/100 g)

Ash (g/roo g)

$$
\begin{aligned}
& 67 \cdot 2 \pm 1 \cdot 59 \\
& 2 \cdot 17 \pm 0.12 \\
& 15 \cdot 3 \pm 1 \cdot 96 \\
& 2 \cdot 14 \pm 0.33 \\
& 207 \\
& 1 \cdot 75 \pm 0.12
\end{aligned}
$$

Mean value with standard deviation

Constituent

$\mathrm{Ca}(\mathrm{mg} / 100 \mathrm{~g})$

$\mathrm{Mg}(\mathrm{mg} / \mathrm{s} 00 \mathrm{~g})$

$\mathrm{P}$ (mg/100 g)

$\mathrm{Na}$ (m-equiv./100 g)

$\mathrm{K}$ (m-equiv./100 g) for seven samples

$$
\begin{aligned}
& 517 \pm 46 \cdot 1 \\
& 35 \cdot 7 \pm 4 \cdot 86 \\
& 274 \pm 28 \cdot 2 \\
& 3.88 \pm 1 \cdot 13 \\
& 4.08 \pm 0.50
\end{aligned}
$$

Table I shows the mean composition of rabbit's milk. The flow of colostrum must have been over before the $4^{\text {th }}$ day, for no consistent trends were brought out by the separate analyses, and the results have been averaged and the mean values used for subsequent calculations. The milk contained about 10\% less water than the young it was produced to feed. The figures for the $\mathrm{N}$, fat and lactose resemble those given in the literature (Blaxter, I96r); the figures for the minerals are possibly the first to have 
been obtained. Of this milk, $100 \mathrm{~g}$ provided $207 \mathrm{kcal}$, of which about $27 \%$ came from protein, nearly $70 \%$ from fat and only $4 \%$ from lactose. The last is much lower than the figure for human milk or cow's milk, but the ratio of fat calories to carbohydrate calories was lower in these milks than the one given for ralbbit's milk by Blaxter (196r). It is of the same order as the figures given in the same tatle for milk of the guinea-pig and some of the other small mammals.

\section{Table 2. Dimensions of the digestive tract}

(Mean values with standard deviations for nine ribbits at each age)

Age (days)
Body-weight (g)
Empty body weight (excluding gut
contents) (g)
Weight of stomach $(\mathrm{g})$
Weight of small intestine $(\mathrm{g})$
Length of small intestine $(\mathrm{cm})$
Weight of small intestine $(\mathrm{g} / \mathrm{cm})$
Weight of large intestine $(\mathrm{g})$
Stomach as $\%$ of empty body weight
Small intestine as $\%$ of empty
body weight
Large intestine as $\%$ of empty
body weight

$\begin{array}{lll}<1 & 3 & 11 \\ 50.2 \pm 5.12 & 71.3 \pm 4.46 & 157 \pm 16.6 \\ 46.8 \pm 4.1 & 65.0 \pm 5.04 & 138 \pm 12.0 \\ & & \\ 0.39 \pm 0.17 & 0.99 \pm 0.15 & 2.74 \pm 0.85 \\ 1.08 \pm 0.40 & 1 \cdot 10 \pm 0.44 & 2.14 \pm 0.66 \\ 60.6 \pm 4.35 & 74.6 \pm 7.15 & 112 \pm 10.6 \\ 0.018 \pm 0.0065 & 6.015 \pm 0.0055 & 0.019 \pm 0.0063 \\ 0.33 \pm 0.07 & 0.49 \pm 0.14 & 1.49 \pm 0.25 \\ 0.85 \pm 0.38 & 1.52 \pm 0.26 & 1.98 \pm 0.58 \\ 2.35 \pm 0.94 & 1.72 \pm 0.74 & 1.56 \pm 0.52 \\ 0.74 \pm 0.17 & 0.75 \pm 0.19 & 1.08 \pm 0.18\end{array}$

'Table 2 shows the mean weight of nine young animals at birth, at 3 days and at I days of age, before and after removal of the contents of the digestive tract. The dimensions of the stomach and small and large intestines are also given. The stomach constituted nearly $\mathrm{x} \%$ of the body-weight at birth and alrost $2 \%$ at I I-I 2 days. These figures are two or three times higher than the ones found for suckling rats or pigs (Widdowson \& Dickerson, unpublished observations) and are in line with the unusual suckling behaviour of the young rabbit. In spite of the $24 \mathrm{~h}$ period without food there was always some milk left in the stomach at the end of this time, and the delivery of nutrients into the duodenum for digestion and absorption was evidently continuous. The weight of the large intestine increased like that of the stomach, but its contribution to the weight of the body rose more slowly, from 0.74 to $1 \cdot 1 \%$. For the first $3-4$ days the small intestine gained weight less rapidly than the rest of the body, and this trend went on for the next 8 days, so that its weight, u.like that of the stomach and large intestine, fell continuously as a percentage of the body-weight. In contrast to the stomach, the small intestine forms a smaller proporticin of the body-weight in the suckling rabbit than it does in the suckling rat or pig. 'The table also shows that the growth in weight of the small intestine was accompanied by growth in length, and there was no significant change in the weight per unit length.

Table 3 shows the mean chemical composition of the eight young rabbits analysed at birth, at 3 days and at $I$ d days of age. Comparison of the figures for day o with those for day 3 shows that within this period the weight increased, but the percentage of fat fell $(P<0.05)$. The concentrations of $\mathrm{Na}$ and $\mathrm{Cl}$ in the fat-free body tissue also 
decreased significantly $(P<0.01$ for each). If now the figures for day 3 are compared with those for day II it will be seen that by II days the weight had doubled, the percentage of water in the fat-free body tissue had fallen considerably $(P<0.01)$, while the concentrations of $\mathrm{N}, \mathrm{K}, \mathrm{Ca}, \mathrm{Mg}$ and $\mathrm{P}$ in the fat-free body tissue had materially increased $(P<0.01$ for all five constituents).

\section{'Table 3. Chemical composition of the whole bodies of young rabbits} and of the fat-free body tissue

(Mean values with standard deviations for eight rabbits at each age)

Age (days)

Empty body weight (excluding gut contents) (g)

Water (g/roog)

Fat $(\mathrm{g} / \mathrm{r} 00 \mathrm{~g})$

Water $(\mathrm{g} / \mathrm{r} 00 \mathrm{~g})$
$\mathrm{N}(\mathrm{g} / \mathrm{l} 00 \mathrm{~g})$
$\mathrm{Ca}(\mathrm{mg} / \mathrm{l} 00 \mathrm{~g})$
$\mathrm{Mg}(\mathrm{mg} / \mathrm{l} 00 \mathrm{~g})$
$\mathrm{P}(\mathrm{mg} / \mathrm{l} 00 \mathrm{~g})$
$\mathrm{Na}(\mathrm{m}$-equiv./100 g)
$\mathrm{K}$ (m-equiv./100 g)
$\mathrm{Cl}(\mathrm{m}$-equiv./100 g)

Whole body

$\begin{array}{lll}<1 & 3 & 11 \\ 47.7 \pm 4.9 & 64.7 \pm 5 \cdot 5 & 139 \pm 12 \cdot 0 \\ 79.7 \pm 0.65 & 80 \cdot 5 \pm 1 \cdot 4 & 76 \cdot 1 \pm 1 \cdot 3 \\ 4.5 \pm 0.99 & 3 \cdot 0 \pm 1 \cdot 58 & 4 \cdot 6 \pm 1 \cdot 69\end{array}$

Fat-free body tissue

$\begin{array}{lll}83.4 \pm 1.30 & 83.1 \pm 0.65 & 79.8 \pm 0.72 \\ 2.02 \pm 0.18 & 2 \cdot 19 \pm 0.14 & 2.58 \pm 0.15 \\ 624 \pm 79 & 594 \pm 60 & 810 \pm 75 \\ 31.2 \pm 3.6 & 32.4 \pm 3.0 & 41.5 \pm 3.7 \\ 452 \pm 43 & 435 \pm 30 & 539 \pm 13 \\ 7.37 \pm 0.46 & 6.60 \pm 0.17 & 6.35 \pm 0.26 \\ 5.59 \pm 0.71 & 5.98 \pm 0.37 & 6.42 \pm 0.26 \\ 4.93 \pm 0.26 & 4.44 \pm 0.24 & 4.09 \pm 0.44\end{array}$

Table 4. Percentage of the nutrients in the milk incorporated into the bodies of young rabbits while they doubled their weights between the $3^{\text {rd }}$ and I Ith day

$\begin{array}{lccc}\text { Constituent } & \begin{array}{c}\% \text { in- } \\ \text { corporated }\end{array} & \text { Constituent } & \begin{array}{c}\% \text { in- } \\ \text { corporated }\end{array} \\ \text { Water } & 60 & \mathrm{Na} & 8 \mathbf{1} \\ \text { Calories } & 27 & \mathrm{Ca} & 97 \\ \text { Protein (as N) } & 72 & \mathrm{Mg} & 7 \mathbf{1} \\ \text { K } & 88 & \mathbf{P} & 100\end{array}$

Table 4 shows the percentages of the constituents found in the milk which were incorporated into the bodies of the young between the $3^{\text {rd }}$ and the $\mathrm{I}$ ith day after birth. The figures have been arrived at from the mean composition of the litter-mates analysed at 3 days, the mean composition of the milks and of the amounts taken, and lastly the composition of the bodies analysed at I I days. Both water and calories were required in appreciable amounts for the services of the body, which explains why their retentions are less than those of $\mathrm{N}$ and minerals, but even so only $40 \%$ of the intake of water was lost by evaporation and excretion, and about $70 \%$ of the calories used for cellular metabolism and thermal regulation. Of the $\mathrm{Na}, 8 \mathrm{I} \%$ was retained in spite of the falling percentage of $\mathrm{Na}$ in the body. The retentions of $\mathrm{Ca}$ and $\mathrm{P}$ were virtually complete and exceeded the percentages for $\mathrm{K}$ and $\mathrm{Mg}$. 


\section{DISCUSSION}

\section{The first 3 days}

Growth was slower during the first 3 days than it was afterwards. The exact intakes of colostrum and milk were not determined during this time because the doe tended to reject her young if she was shut away from them in the first 2 days after delivery. Changes in the $\mathrm{N}, \mathrm{K}, \mathrm{Na}$ and $\mathrm{Cl}$ indicate that some cellular growth took place, and consequently there was some reduction of the extracellular space; nevertheless the percentage of water in the fat-free body tissue did not change appreciably and the percentage of fat fell rather than rose. 'The percentage of fat in the body is commonly higher at the end of the suckling period than it is at the time of birth, in rabbits as well as in other mammals (Spray \& Widdowson, 1950), but: the rise evidently does not begin until after the 3 rd day, and it seems likely that young rabbits pass through a period of partial undernutrition during the first 3 days after birth. A similar period of undernutrition was described in guinea-pigs by Widdowson \& McCance (1955) and was considered to be physiological.

The concentration of $\mathrm{Ca}$ and $\mathrm{P}$ in the body fell, suggesting that calcification was lagging behind the growth of the bones. This has previously been shown to be so in the rabbit at this time of life (Weidmann \& Rogers, 1958), and applies also to kittens, puppies and human babies during the early part of the suckling period (Burns \& Henderson, 1936; Weidmann \& Rogers, 1958; Dickerson, 1962). Evidence has been adduced by Widdowson, McCance, Harrison \& Sutton (1963) that in a breast-fed baby $\mathrm{P}$ may be the factor limiting bone mineralization in the first week or two of extrauterine life. The administration of more $P$ increased the retention, not only of $P$, but also of $\mathrm{Ca}$ and $\mathrm{Mg}$. Slater \& Widdowson (1962) suggested that in kittens $\mathrm{Ca}$, not $\mathrm{P}$, may be the factor restricting calcification during the early part of suckling, and evidently each species requires separate consideration. The experiments now described do not indicate whether $\mathrm{Ca}$ or $\mathrm{P}$ is the limiting factor in rabbits, for the retention of both was complete and no supplementation experiments were made. Urine was collected from three suckling rabbits and was found to contain only traces of both $\mathrm{Ca}$ and $\mathrm{P}$.

The weight of the small intestine, which must be low on the list of 'growth priorities' at this age in spite of its importance in functional development, increased, but there was no significant change in the weight per unit length. The stomach on the other hand, which is a large organ at birth, grew more rapidly than the body as a whole. The role of the rabbit's stomach as a reservoir appears to be carried through into adult life (Carmichael, Strickland \& Driver, 1945; Alexander \& Chowdhury, 1958).

\section{The doubling of the weight between the $3^{\text {ril }}$ and $\mathrm{I}$ th days}

Table 5 sets out the intake of calories and protein while the young rabbits doubled their weights between the $3^{\mathrm{rd}}$ and $\mathrm{I}$ ith day after birth. Set out in this way, they extend the information about the rat, pig, calf and man collected by McCance \& Widdowson (1964) and may be compared directly with them. The body-weights of the young rabbits were about $65 \mathrm{~g}$ when the experiments began and consequently they fell 
between those of the rat and pig which are 5 and $1400 \mathrm{~g}$ respectively. Their intakes of calories and proteins were also intermediate, but very different from those of either the rat or the pig. Yet, because they grew nearly as fast, it might have been predicted from the previous work that their intakes both of calories and proteins per $g$ of gain in weight or per $g$ of mean weight per day would have been very much the same. And so they turned out to be.

'Table 5. Mean values for eight rabbits for intake and utilization of calories and protein from the $3^{\text {rd }}$ to the $1 \mathrm{I}$ th day after birth

(Weight at 3 days $65 \mathrm{~g}$; weight at 11 days $139 \mathrm{~g}$; mean weight over this time $102 \mathrm{~g}$ )

$\begin{array}{lcc} & \text { Calories (kcal) } & \text { Protein (g) } \\ \text { Total intake } & 272 & 18.2 \\ \text { Intake/g mean weight } & 2.7 & 0.17 \\ \text { Intake/g gain } & 3.7 & 0.25 \\ \text { Intake/g mean weight per day } & 0.33 & 0.02\end{array}$

Table 6. Intake of calories (kcal) from the $3^{\text {rd }}$ to the I ith day in rabbits and in other species while the birth weight is doubling

$\begin{array}{lcccc}\text { Species } & \begin{array}{c}\text { Per g mean } \\ \text { weight/day }\end{array} & \begin{array}{c}\text { Per g mean } \\ \text { weight }\end{array} \text { 0.72/day } & \text { Per g protein } & \begin{array}{c}\text { Per g protein } \\ \text { used for growth }\end{array} \\ \text { Rat } & 0.40 & 0.72 & 20 & 27 \\ \text { Rabbit } & 0.33 & 0.92 & 15 & 21 \\ \text { Pig } & 0.44 & 4.08 & 16 & 40 \\ \text { Ox (calf) } & 0.12 & 2.75 & 22 & 90 \\ \text { Man } & 0.12 & 1.45 & 60 & 280\end{array}$

'Table 6 gives some instructive comparisons between the rat, rabbit, pig, calf and man. Some of the figures in the second column have already received comment. The relationships displayed in the third column are at present very puzzling. They were discussed by McCance \& Widdowson (1964) and raise the whole question of what metabolic rates imply per unit of body-weight and per unit of surface area (Kleiber, 1961). The figures in the fourth column are merely an expression of the protein: calorie ratios in the five milks. The value for intake of calories per $\mathrm{g}$ protein used for growth for the rabbit is close to that for the rat, lower than that for the pig and much lower than those for the calf or human baby. These figures depend upon the rate of lean body growth, the deposition of fat and the expenditure of calories on thermal regulation. Figures as low as those for the rat or rabbit should be expected only in animals with intensely rapid rates of cell growth, living in favourably warm environments on milks with a high protein:calorie ratio.

\section{S U M MAR Y}

1. Young rabbits are generally suckled only once in $24 \mathrm{~h}$. They double their birth weights by about the 6th day and they also double their weights between the 3 rd and the I I th days.

2. The young from nine litters were weighed before and after each feed from the $3^{\text {rd }}$ to the 1 ith day and milk from their own and other mothers was analysed. The 
bodies of newborn and 3- and II-day-old animals we:e also analysed. It was thus possible to follow the intakes and retentions of nutrient: in the early days of postnatal life.

3. There was some evidence of slight undernutrition for the first 3 days after birth.

4. Between the $3^{\text {rd }}$ and the I Ith day the animals retained $60 \%$ of their intake of water, about $70 \%$ of their intakes of nitrogen and magnesium, $80-90 \%$ of their intakes of sodium and potassium and the whole of the dietary calcium and phosphorus.

The authors are grateful to Miss P. Pledger for her assistance with the animals.

\section{REFERENCES}

Alexander, F. \& Chowdhury, A. K. (1958). Brit. F. Nutr. 12, 65

Association of Official Agricultural Chemists (1950). Official Metizods of Analysis, 7 th ed. Washington, DC: Association of Official Agricultural Chemists.

Bernard, M. C. (1865). Introduction à l'Étude de la Médicine expérimentale. Paris: J. B. Baillière et Fils. Blaxter, K. L. (1961). In Milk: The Mammary Gland and its Secretion. Vol. 2, p. 305. [S. K. Kon and A. T. Cowie, editors.] New York: Academic Press Inc.

Burns, C. M. \& Henderson, N. (1936). Biochem. F. 30, 1207.

Cabak, V., Dickerson, J. W. T. \& Widdowson, E. M. (1963). Brit. Y. Nutr. 17, 601.

Carmichael, E. B., Strickland, J. T. \& Driver, R. L. (1945). Amır. F. Physiol. 143, 562.

Deutsch, J. A. (x957). Brit. F. Anim. Behav. 5, 53.

Dickerson, J. W. T. (r962). Biochem. 7. 82, 56 .

Kleiber, M. (196r). The Fire of Life. New York: John Wiley and Sons Inc.

McCance, R. A. \& Widdowson, E. M. (Ig64). In Mammalian Protein Metabolism. Vol. 2, p. 226 [H. N. Munro and J. B. Allison, editors.] New York: Academic Piess Inc.

Short, D. J. \& Gammage, L. (1959). I. Anim. Tech. Ass. 9, 62.

Slater, J. E. \& Widdowson, E. M. (1962). Brit. F. Nutr. 16, 39.

Spray, C. M. \& Widdowson, E. M. (1950). Brit. J. Nutr. 4, 332.

Thomas, K. (I91 I). Arch. Anat. Physiol. p. 9.

Wallace, W. M., Weil, W. B. \& Taylor, A. (1958). Ciba Fdn Colloq. Ageing, 4, II6.

Weidmann, S. M. \& Rogers, H. J. (1958). Biochem. J. 69, $33^{8}$.

Widdowson, E. M. \& McCance, R. A. (r955). Brit. J. Nutr. 9, 316.

Widdowson, E. M., McCance, R. A., Harrison, G. E. \& Sutton, A. (1963). Lancet, ii, 1250. 